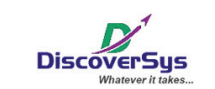

Published by DiscoverSys

\title{
Predictors of Loss To Follow Up and Mortality Among Children $\leq 12$ Years Receiving Anti Retroviral Therapy during the First Year at a Referral Hospital in Bali
}

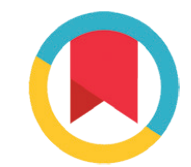

CrossMark

\section{ABSTRACT}

Background and purpose: Many HIV-infected children in Bali have started antiretroviral therapy (ART), but loss to follow up (LTFU) is a continuing concern, and the issue of childhood adherence is more complex compared to adults.

Methods: This was a retrospective study among cohort of 138 HIV+ children on ART in Sanglah General Hospital, Denpasar, Bali from January 2010 to December 2015. Kaplan-Meier analysis was used to describe incidence and median time to LTFU/mortality and Cox Proportional Hazard Model was used to identify predictors. Variables which were analysed were socio-demographic characteristics, birth history, care giver and clinical condition of the children.

Results: Mean age when starting ARV therapy was 3.21 years. About $25 \%$ experienced LTFU/death by 9.1 month resulting in an incidence rate of 3.28 per 100 child month. The higher the WHO stage, the higher the risk for LTFU/mortality along with low body weight (AHR=0.90; 95\%(l: 0.82-0.99).

Conclusion: Clinical characteristics were found as predictors for LTFU/ mortality among children on ART.

Keywords: Loss to follow up, mortality, paediatric, ART, Indonesia

Cite This Article: Juergens,S., Sawitri, A.A.S., Wati, K.D.K., Putra, I.W.G.A.E., Merati, T.P. 2016. Predictors of Loss To Follow Up and Mortality Among Children $\leq 12$ Years Receiving Anti Retroviral Therapy during the First Year at a Referral Hospital in Bali. Public Health and Preventive Medicine Archive 4(2): 101-106. D01:10.15562/phpma.v4i2.65

\section{Prediktor Lost To Follow Up dan Kematian pada Anak-anak $\leq 12$ Tahun, yang Menerima Terapi Anti-Retroviral pada Tahun Pertama di Rumah Sakit Pusat Rujukan di Bali}

${ }^{1}$ Public Health Postgraduate Program Udayana University, ${ }^{2}$ Department of Community and Preventive Medicine Faculty of Medicine University Udayana, ${ }^{3}$ Department of Paediatrics Faculty of Medicine University Udayana/ RSUP Sanglah,

${ }^{4}$ School of Public Health Faculty of Medicine Udayana University, ${ }^{5}$ Department of Internal Medicine Faculty of Medicine University Udayana/RSUP Sanglah

*Correspondence to:

Stefanie Juergens, Public Health

Postgraduate Program Udayana University

nanijuergens@gmail.com demografis pasien, riwayat persalinan, pengasuh dan karakteristik klinis. memperoleh terapi antiretroviral (ART) di Bali, jumlahnya cukup banyak, akan tetapi lost to follow up (LTFU) masih cukup substansial. LTFU dan kematian pada anak yang sedang dalam ART berbeda dan lebih kompleks dibandingkan dengan orang dewasa.

Metode: Desain penelitian adalah retrospektif pada kohor sebanyak 138 anak HIV positif yang menerima ART di Rumah Sakit Umum Pusat Sanglah, Denpasar Bali antara Januari 2010 sampai Desember 2015. Analisis Kaplan-Meier digunakan untuk menggambarkan tingkat kejadian dan waktu median untuk kematian. Cox Proportional Hazard Model digunakan untuk mengidentifikasi prediktornya. Variabel yang dianalisa adalah karakteristik sosio-
Hasil:Mean usia ketika anak mulaiterapi ARV adalah 3,21 tahun. Sebanyak 25\% mengalami LTFU atau kematian dalam waktu 9,1 bulan sehingga tingkat kejadian 3,28 per 100 anak-bulan. Anak dengan Stadium WHO yang lebih tinggi saat memulai ART, mempunyai risiko untuk LTFU dan atau kematian. Variabel yang dijumpai sebagai prediktor LTFU dan kematian adalah berat badan rendah ketika anak datang pertama kali ke rumah sakit ( $\mathrm{AHR}=0,90 ; 95 \% \mathrm{Cl}: 0,82-0,99$ ), sedangkan karakteristik sosio-demografis, riwayat persalinan, dan pengasuh tidak dijumpai sebagai prediktor.

Simpulan: Karakteristik klinis dijumpai sebagai prediktor LFTU atau kematian pada anak dengan ART. 


\section{BACKGROUND}

The UNAIDS estimated that in 2013 there were 25,000 (16,000-37,000) children aged 0-14 months living with HIV in Indonesia. ${ }^{1}$ Paediatric ART coverage globally is still lagging behind with 1 in 4 children receiving these life-prolonging medications, compared to 1 in 3 adults. ${ }^{2}$

Since drug treatment has no definite timeframe, people living with HIV will most likely take the medication for the rest of their lives, possibly contributing to lost to follow up (LTFU). ${ }^{3}$ Nevertheless there is a paucity of data on the rates of LTFU from HIV care and concerning the factors associated with LTFU especially in resource-limited settings. ${ }^{4}$ Additionally the situation of LTFU in children is vastly different and more complex when compared to adults: children are dependent on their caregivers, and the child's outcome may be linked to predicament of the caregiver. ${ }^{5}$

A high mortality rate, especially in the first 3 months of ART initiation, is owing to the fact that many children start treatment at an advanced stage of illness, particularly in resource-poor settings. Such death might be misclassified as early LTFU if not appropriately reported. ${ }^{6}$

Sanglah General Hospital in Denpasar is the central referral hospital for the Province of Bali Indonesia, as well as for other provinces that lie to the east of Bali such as West and East Nusa Tenggara. In addition, Sanglah General Hospital is the largest service provider in the province of Bali capacitated in providing ARV therapy to children. The majority of children were referred to the hospital from outside clinics or hospitals and only very few came from the prevention of mother to child transmission (PMTCT) program.

This study was the first to explore the predictors of LTFU and mortality in HIV+ children in Bali.

\section{METHOD}

A retrospective longitudinal survival analysis was performed in Sanglah General Hospital in Denpasar. The medical records of children enrolled in the ARV therapy program from $1^{\text {st }}$ of January 2010 till $31^{\text {st }}$ of December 2015 of the Paediatric Department, were incorporated, resulting in a total of 211 medical records. Records were examined especially regarding patients who were continually taking ARV for 12 months or longer or who were LTFU/died prior the 12 month-mark. Any patients that were transferred within the first year of ART or enrolled $<4$ month before database closure were excluded. The hospital defines "children" up to the age of 12 years old.

LTFU was defined as not returning to the hospital for 90 days or longer after the last appointment during the first year of ART. If the patient returns after 90 days of LTFU and re-accesses therapy only the first LTFU will be counted and further initiation will be excluded. However, if a child is LTFU due to death is difficult to determine if the child did not die in the hospital. Therefore LTFU and mortality were grouped as one in this study and not analysed separately.

In this study the predictors for LTFU were grouped into three groups: children's demographic characteristics, socioeconomic background and children's clinical condition, including: gender, address, age at first visit, age at ARV initiation, ARV starting year, primary care giver (PCG) characteristics, WHO stage at first visit and at starting ART, ${ }^{7}$ weight (kg) at first visit, haemoglobin state, $\mathrm{CD} 4 \%$, $\mathrm{CD} 4$ cell count total, presence of malnutrition, $\mathrm{TB}$, and anaemia. All data were reviewed as recorded in the medical record.

The collected data were analysed by STATA version 12. Survival analysis was carried out as analysis of median time to LTFU/mortality. KaplanMeier analysis was used to demonstrate survival analysis per month. Cox proportional hazards model was used to analyse the significance of the independent variables towards LTFU/mortality. The Cox regression model using the stepwise method was based on the bivariate analysis with a p-value $<0.10$.

Ethical clearance approval was obtained from the Ethical Committee from School of Medicine Udayana University/Sanglah General Hospital. Data were anonymized and handled confidentially during all phases of research activities.

\section{RESULT}

Total number of subjects analysed were 138, as 41 were excluded and 32 medical records could not be found. Of the total subjects, 37 were LTFU and 6 died within the first year of ARV therapy.

The overall median age during the first visit was 2.6 years old and when starting ART was 3.21 years old. In the LTFU/mortality group, the children were much younger compared to the group that continued. With each year of age, at the first visit, there is a $17 \%(\mathrm{HR}=0.83)$ higher chance in continuing therapy. In both groups ART was initiated about 6 months after the first visit. Variables such as gender, address, starting year or PCG did not show any significance.

The result of Kaplan-Meier analysis related to median time of LTFU/death is shown in Figure 1. Of all patients receiving ART, 25\% experienced LTFU/ death by 9.1 months resulting in an incidence rate of 3.28/100 child-month. The median time of $50 \%$ of LTFU and mortality within 12 months of ARV therapy, was not calculated in this study. 


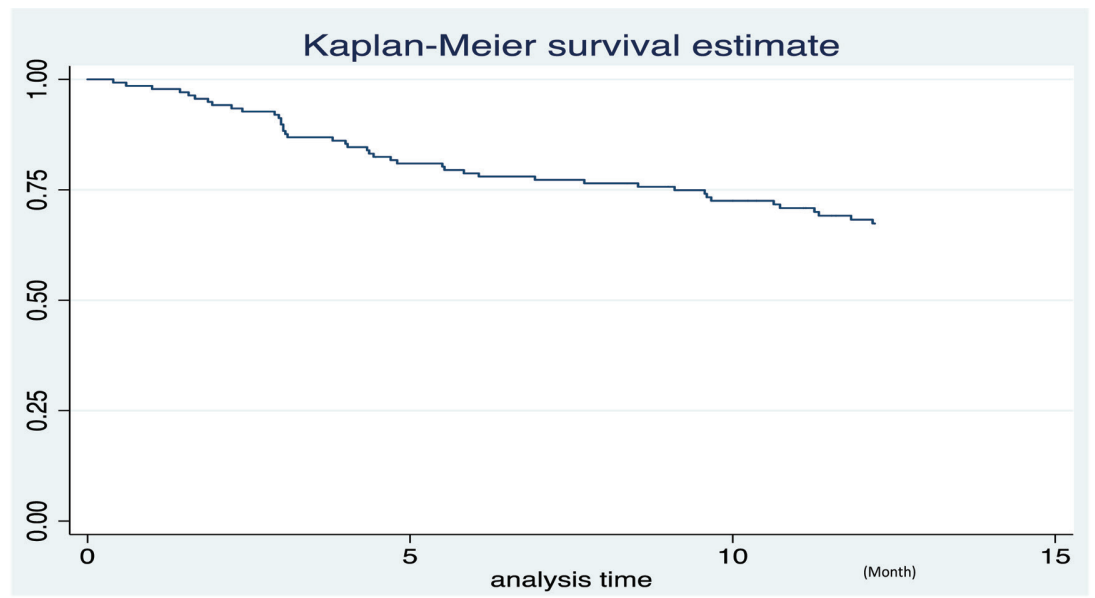

The most common main complaint during the first visit was diarrhoea (20.29\%), followed by shortness of breath (15.94\%) and fever (14.49\%). Less than $10 \%$ directly consulted to VCT without any underlying health problem.

In general, children who experienced LTFU/ death arrived at the hospital at a higher WHO stage. However, only the WHO staging at the time of ART initiation was significant $(\mathrm{p}=0.01)$. Table 1 also shows the higher the WHO stage the higher the chance of LTFU/mortality.

The children, who continued therapy $>1$ year had a $2.5 \mathrm{~kg}$ higher median weight compared to the children that were LTFU/death. With each increase

Figure 1 Kaplan-Meier Survival Estimate

Table 1 Significance of children's characteristics towards LTFU/mortality

\begin{tabular}{|c|c|c|c|c|c|}
\hline Characteristics & $\begin{array}{l}\text { LTFU } \\
\text { n (\%) }\end{array}$ & $\begin{array}{c}\text { Not LTFU } \\
\text { n (\%) }\end{array}$ & Hazard ratio & $95 \% \mathrm{Cl}$ & p value \\
\hline \multicolumn{6}{|l|}{ Gender } \\
\hline Boy & $21(27.27)$ & $56(72.73)$ & Ref & & \\
\hline Girl & $22(36.07)$ & $39(63.93)$ & 0.72 & $0.40-1.31$ & 0.284 \\
\hline \multicolumn{6}{|l|}{ Address } \\
\hline Denpasar & $12(33.33)$ & $24(66.67)$ & Ref & & \\
\hline Outside of Denpasar & $30(31.58)$ & $65(68.42)$ & 0.89 & $0.46-1.75$ & 0.60 \\
\hline Missing & $1(14.29)$ & $6(85.71)$ & 0.35 & $0.05-2.68$ & \\
\hline \multicolumn{6}{|l|}{ Age at first visit (years) } \\
\hline Median (IQR) & $1.42(0.93-3.24)$ & $2.99(1.59-4.63)$ & 0.83 & $0.70-0.98$ & 0.024 \\
\hline \multicolumn{6}{|c|}{ Age at ARV initiation (years) } \\
\hline Median (IQR) & $2.03(0.52-3.73)$ & $3.64(1.12-4.91)$ & 0.84 & $0.72-0.99$ & 0.035 \\
\hline \multicolumn{6}{|l|}{ ARV starting year } \\
\hline 2010 & $4(20.00)$ & $16(80.00)$ & Ref & & \\
\hline 2011 & $2(16.67)$ & $10(83.33)$ & 0.83 & $0.15-4.54$ & 0.48 \\
\hline 2012 & $10(41.67)$ & $14(58.33)$ & 2.46 & $0.78-7.75$ & \\
\hline 2013 & $12(35.29)$ & $22(64.71)$ & 2.04 & $0.66-6.34$ & \\
\hline 2014 & $10(40.00)$ & $15(60.00)$ & 2.46 & $0.77-7.85$ & \\
\hline 2015 & $5(21.74)$ & $18(78.26)$ & 1.67 & $0.44-6.26$ & \\
\hline \multicolumn{6}{|l|}{ Primary care giver } \\
\hline Both parents & $9(47.37)$ & $10(52.63)$ & Ref & & \\
\hline Mother/father & $20(25.97)$ & $57(74.03)$ & 0.48 & $0.22-1.07$ & 0.430 \\
\hline Extended family & $5(33.33)$ & $10(66.67)$ & 0.66 & $0.22-1.97$ & \\
\hline NGO & $1(16.67)$ & $5(83.33)$ & 0.36 & $0.05-2.83$ & \\
\hline Missing & $8(38.10)$ & $13(61.90)$ & 0.75 & $0.29-1.96$ & \\
\hline \multicolumn{6}{|l|}{ WHO stage at first visit } \\
\hline Stage 1 & $5(20.83)$ & $19(79.17)$ & Ref & & \\
\hline Stage 2 & $7(25.00)$ & $21(75.00)$ & 1.17 & $0.37-3.69$ & 0.168 \\
\hline Stage 3 & $13(26.00)$ & $37(74.00)$ & 1.26 & $0.45-3.54$ & \\
\hline Stage 4 & $16(55.17)$ & $13(44.83)$ & 3.21 & $1.18-8.77$ & \\
\hline Missing & $2(28.57)$ & $5(71.43)$ & 1.47 & $0.29-7.58$ & \\
\hline
\end{tabular}


Table 1 Significance of children's characteristics towards LTFU/mortality

\begin{tabular}{|c|c|c|c|c|c|}
\hline Characteristics & $\begin{array}{l}\text { LTFU } \\
\text { n (\%) }\end{array}$ & $\begin{array}{c}\text { Not LTFU } \\
\text { n (\%) }\end{array}$ & Hazard ratio & $95 \% \mathrm{Cl}$ & p value \\
\hline \multicolumn{6}{|c|}{ WHO stage starting ART } \\
\hline Stage 1 & $2(10.53)$ & $17(89.47)$ & Ref & & \\
\hline Stage 2 & $5(22.73)$ & $17(77.27)$ & 2.29 & $0.45-11.82$ & 0.01 \\
\hline Stage 3 & $16(27.59)$ & $42(72.41)$ & 2.97 & $0.68-12.93$ & \\
\hline Stage 4 & $17(51.52)$ & $16(48.48)$ & 6.63 & $1.53-28.72$ & \\
\hline Missing & $5(50.00)$ & $3(50.00)$ & 5.58 & $0.93-33.42$ & \\
\hline \multicolumn{6}{|c|}{ Weight at first visit (kg) } \\
\hline Median (IQR) & $7.5(3.7)$ & $10(4.2)$ & 0.88 & $0.80-0.97$ & 0.007 \\
\hline \multicolumn{6}{|c|}{ Haemoglobin (gr/dl) } \\
\hline Median (IQR) & $10.1(2.1)$ & $10.6(2.3)$ & 0.99 & $0.99-1.00$ & 0.406 \\
\hline \multicolumn{6}{|l|}{$\mathrm{CD} 4 \%$} \\
\hline Median (IQR) & $9(18)$ & $10(13.6)$ & 1.00 & $1.00-1.01$ & 0.050 \\
\hline \multicolumn{6}{|l|}{ CD4 cell count } \\
\hline Median (IQR) & $289.5(462)$ & 264 (419) & 1.00 & $0.99-1.00$ & 0.629 \\
\hline \multicolumn{6}{|l|}{ Malnutrition } \\
\hline Yes & $22(47.83)$ & $24(52.17)$ & Ref & & \\
\hline No & $21(22.83)$ & $71(77.17)$ & 2.57 & $1.41-4.67$ & 0.002 \\
\hline \multicolumn{6}{|l|}{ Tuberculosis } \\
\hline Yes & $6(18.18)$ & $27(81.82)$ & Ref & & \\
\hline No & $37(35.24)$ & $68(64.76)$ & 0.46 & $0.19-1.07$ & 0.074 \\
\hline \multicolumn{6}{|l|}{ Anaemia } \\
\hline Yes & $14(66.67)$ & $7(33.33)$ & Ref & & \\
\hline No & 29 (24.79) & $88(75.21)$ & 4.62 & $2.42-8.82$ & 0.001 \\
\hline
\end{tabular}

Table 2 Multivariate analyses of predictors for LTFU/mortality in children receiving ARV therapy

\begin{tabular}{|c|c|c|c|c|}
\hline \multirow[b]{2}{*}{ Variables } & \multirow[b]{2}{*}{ Adjusted hazard ratio } & \multicolumn{2}{|c|}{$95 \% \mathrm{Cl}$} & \multirow[b]{2}{*}{ p value } \\
\hline & & Lower & Upper & \\
\hline $\mathrm{CD} 4 \%$ & 1.000 & 0.99 & 1.00 & 0.060 \\
\hline WHO staging starting ARV & 1.158 & 0.99 & 1.35 & 0.065 \\
\hline Weight at first visit & 0.903 & 0.82 & 0.99 & 0.036 \\
\hline
\end{tabular}

of one kilogram, there is a protective factor of $12 \%$ (AHR=0.88; 95\%CI: 0.803-0.966).

Malnutrition was the most common opportunistic infection (OI) over all. The highest risk for LTFU/death was in children with anaemia, with a risk of $4.62(\mathrm{AHR}=4.62$; 95\%CI: 2.42-8.82). A child with malnutrition had a 2.57 higher (AHR=2.57; 95\%CI: 1.41-4.67) chance of LTFU/ death compared to a child with normal/good nutrition (Table 1).

Variables entered in the step-wise regression model, were: age at first visit (years), age at ARV initiation (years), WHO stage when starting ART, weight at first visit, and CD4\%. The results are shown in Table 2.
Even though CD4\% as well as WHO staging are not significant in this model, they are still included due to their pathophysiological reasons. It is important to note that WHO staging and weight do not correlate in this study.

\section{DISCUSSION}

This study was the first to explore LTFU and mortality in children receiving ARV therapy in Bali.

A total of $69.84 \%$ (95 cases) continued to take ARV therapy for more than 12 months, and $31.16 \%$ (43 cases) discontinued therapy, within the first year of initiation. The overall incidence rate of LTFU and mortality combined was 3.28 per 100 child-month. 
Comparing it to other studies is problematic since most studies do not combine LTFU and mortality. In HIV infected children in Asia LTFU and death rates were 4.2 (3.7-4.8) and 2.1 (1.7-2.5) per 100 person-years, respectively. ${ }^{8}$

A total of $65.94 \%$ of children started ART at stage III/IV. The higher the WHO stage when starting the ARV therapy, the higher the risk for LTFU/ mortality (Table 1). Hence, it can be assumed that the majority, which are LTFU might have died, and therefore did not return to the hospital. Some children presented when already very unwell, and their general health status needed to be addressed before ARV therapy could be given. The overall high number of malnutrition provides insight into why the overall body weight during the first visit is lower in the LTFU/mortality group. Body weight at first visit is about $2.5 \mathrm{~kg}$ lighter in the LFTU/ mortality group. Therefore, the weight level at the beginning has a protective factor of $10 \%$ (adjusted $\mathrm{HR}=0.903$; 95\%CI: 082-0.99) with each increase of $1 \mathrm{~kg}$ body weight. Many children with HIV-1 infection have chronic problems with linear growth and weight gain which might lead in this case to malnutrition and a worth outcome in the LTFU/ mortality group., ${ }^{910,11}$

Even though WHO staging was not significant in the multivariate analysis, weight and staging considered an important role on a pathological basis. According to WHO staging, children under 15 years with unexplained moderate malnutrition who are adequately responding to standard therapy as stage III. ${ }^{7}$

In low income countries, it is estimated that $50 \%$ of HIV-infected infants will die before the age of two. ${ }^{12}$ The overall median age during the first visit was 2.6 years old and the median age at ARV initiation was 3.21 years indicating a fast and swift diagnostic assessment, compared to the Asian average of 7.0 years $^{8}$ and South African median age of 49 months old (4.08 years). ${ }^{5}$ Overall ARV indication is around 6.5 months after the first visit. This gap can be explained through the overall poor condition in which the children arrive at the hospital. This gap is smaller among 5.24 months children that continue therapy compared to 7.35 months children that are LTFU. The age at first visit and among those who begin ARV was much younger in the group that are LTFU/mortality compared to that of those who will continue therapy. The hazard ratio results in a $17 \%$ increase in possibility that with each year of age the child is more likely to continue therapy, so that the older the child the better the adherence (Table 1). This again may be related to the overall poor physical health of the children when presenting at the hospital. As above, the WHO staging was worth in the LTFU/mortality group. Though if younger children already present in a poorly condition, it would be misleading to directly compare them purely based on age. Moreover drug dosing in younger children is complicated, as dosage increases with weight. Patients must be consistently monitored, in order to ensure that they are receiving adequate doses of each drug to achieve therapeutic levels and fully suppress the virus, while also avoiding toxicities related to excess dosing. ${ }^{13}$ Many medications are also not formulated for easy administration to infants and very young children. Such children require either dispersible tablets or syrup formulations, which are often more expensive than tablets. In the case of syrup these may be less palatable, compromising adherence and efficacy. ${ }^{14}$

Bali is divided into nine districts. Sanglah General Hospital lies in the metropolitan district of Denpasar. Denpasar is also the capital city of the Province of Bali. Therefore it is not surprising that $25.36 \%$ of all HIV cases are living in Denpasar. Nevertheless no significance was found if the child comes from Denpasar or outside of Denpasar, resulting in difficulty for the caregiver to attend the monthly check up. Sanglah General Hospital is the largest centre in Bali that provide ARV therapy to children. Some caregivers have to take a day off and drive several hours to the hospital. Most children had the support of either both biological parents, or one parent (69.57\%), only $10.87 \%$ of the children were raised by extended family members (Table 1 ). However, those who raised the child, did not show a significant to LTFU/death, compared to continuing therapy.

Limitation of this study is the small sample size. In total only 138 eligible samples were analysed out of 211 cases. Another limitation was uncertainty about whether or not the child in question was actually LFTU or had died and therefore was LTFU. Additionally, double entry/reporting of patients might occur, noting that specific identification is needed to sign up to receive ARV treatment in Indonesia.

\section{CONCLUSION}

The incidence of LTFU/mortality was 3.28 per 100 child-month, where 95 (69.84\%) children continued therapy for more than 12 month. The predictor for LTFU/mortality in this study was weight at first visit with a protective factor of $10 \%$ with each increased kilogram. The higher the WHO stage when starting ARV therapy, the higher the risk for LTFU/mortality in this study.

This study found no significant predictors of socio demographic characteristics and clinical conditions such as haemoglobin level or CD4 cell count. 


\section{ACKNOWLEDGEMENT}

This study was initially carried out as a Masters Thesis by Stefanie Jüergens at the University of Udayana, School of Public Health. The authors wish to acknowledge the teaching staff at the Udayana University as well as the Sanglah General Hospital.

\section{REFERENCE}

1. UNAIDS. UNAIDS -Indonesia HIV/AIDS estimates (2013) [Internet]. 2013. Available from: http://www. unaids.org/en/regionscountries/countries/indonesia

2. WHO. HIV/AIDS Fact sheet No360 [Internet]. 2014. Available from: factsheets/fs360/en/

3. Schilkowsky LB, Portela MC, de Castilho Sa M. Factors associated with HIV/AIDS treatment dropouts in a special care unit in the City of Rio de Janeiro, RJ, Brazil. Rev Bras Epidemoil [Internet]. 2011;14(2):187-97. Available from: http://www.scielo.br/pdf/rbepid/v14n2/en_01.pdf

4. Blutinger E, Solomon S, Srikrischna A, Thamburaj E, Ganescha A, Solomon S. Dropout from care among HIV-infected patients enrolled in care at a tertiary HIV care center in Chennai, India. AIDS Care [Internet]. 2014;26(12):1500-5. Available from: http://www.ncbi.nlm. nih.gov/pubmed/25011519

5. Fenner L, Brinkhof MWG, Keisser O, Weigel R, Cornell M. Early Mortality and Loss to Follow-up in HIV-Infected Children starting Antiretroviral Therapy in Southern Africa. Acquir Immune Defic Syndr [Internet]. 2010;54(5):524-32. Available from: http://www.ncbi.nlm. nih.gov/pmc/articles/PMC2925143/

6. Sengayi M, Dwane N, Marinda E, Sipambo N, Failie L, Moultuer H. Predictors of loss to follow-up among children in the first and second years of antiretroviral treatment in Johannesburg, South Africa. Glob Heal Action [Internet]. 2013;6. Available from: http://www.ncbi.nlm. nih.gov/pubmed/23364098
7. WHO. Antiretroviral Therapy for HIV Infection in Infants and Children: Towards Universal Access: Recommendations for a Public Health Approach: 2010 Revision. Geneva; 2010.

8. Hansudewechakul R, Sirisanthana V, Kurniati N, Puthanakit T, Lumbiganon P, Saphonn V, et al. Antiretroviral therapy outcomes of HIV-infected children in the TREAT Asia pediatric HIV observational database. J Acquir Immune Defic Syndr [Internet]. 2010;55(4):503-9. Available from: http://www.ncbi.nlm.nih.gov/pmc/articles/ PMC2975064/ pdf/nihms237367.pdf

9. Miller T, Evans S, Orav E, McIntosh K, Winter H. Growth and body composition in children infected with the human immunodeficiency virus-1. Am J Clin Nutr. 1993;57:588-92.

10. McKinney R, Robertson R, Duke Pedriatric AIDS Clinical Trial Unit. Effect of human immunodeficiency virus infection on the growth of young children. J Pediatr. 1993;123:579-82.

11. Nuetzenadel W. Failure to thrive in childhood. Dtsch Arztebl Int. 2011;108(38):643-9.

12. Newell M, Coovadia H, M C-B, Rollins N, Gaillard P, Dabis F, et al. Mortality of infected and uninfected infants born to HIV-infected mothers in Africa: a pooled analysis. Lancet. 2004;364(9441):1236-43.

13. AIDS INFO Guidelines for the Use of Antiretroviral Agents in Pediatric HIV Infection [Internet]. 2015. Available from: https://aidsinfo.nih.gov/contentfiles/lvguidelines/ pediatricguidelines.pdf

14. Phelps B, Rakhmanina N. Antiretroviral drugs in pediatric HIV-infected patients: pharmacokinetic and practical challenges. Paediatr Drugs. 2011;13(3):175-92.

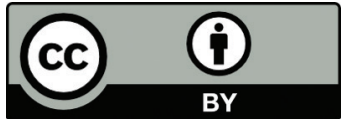

This work is licensed under a Creative Commons Attribution 